\title{
Diminished Agonist-stimulated Inositol Trisphosphate Generation Blocks Stimulus-Secretion Coupling in Mouse Pancreatic Acini during Diet-induced Experimental Pancreatitis
}

Robert E. Powers, Ashok K. Saluja, Mary Jane Houlihan, and Michael L. Steer

Department of Surgery and Dana Research Laboratories and Harvard Digestive Diseases Center, Beth Israel Hospital and Harvard Medical School, Boston, Massachusetts 02115

\begin{abstract}
Young female mice fed a choline-deficient, ethionine-supplemented (CDE) diet rapidly develop acute hemorrhagic pancreatitis. We have observed that pancreatic acini prepared from these mice are unable to secrete amylase in response to addition of the cholinergic agonist carbachol, although they retain the ability to secrete amylase in response to the $\mathrm{Ca}^{2+}$ ionophore A23187. The CDE diet does not alter the binding characteristics ( $K_{d}$ or the maximal number of binding sites) for muscarinic cholinergic receptors as tested using the antagonist $\left[{ }^{3} \mathrm{H}\right] \mathrm{N}$-methylscopolamine nor the competition for this binding by carbachol. Addition of carbachol to acini prepared from mice fed the CDE diet does not result in as marked an increase in cytosolic free $\mathrm{Ca}^{2+}$ levels as that noted in control samples (evaluated using quin2 fluorescence). These observations indicate that the CDE diet interferes with stimulus-secretion coupling in mouse pancreatic acini at a step subsequent to hormone-receptor binding and prior to $\mathrm{Ca}^{2+}$ release. This conclusion is confirmed by our finding that the hormone-stimulated generation of $\left[{ }^{3} \mathrm{H}\right]$ inositol phosphates (inositol trisphosphate, inositol bisphosphate, and inositol monophosphate) from acini labeled with $\left[{ }^{3} \mathbf{H}\right]$ myoinositol is markedly reduced in acini prepared from mice fed the CDE diet. This reduction is not due to a decrease in phosphatidylinositol-4,5-bisphosphate. This communication represents the first report of a system in which a blockade of inositol phosphate generation can be related to a physiologic defect and pathologic lesion.
\end{abstract}

\section{Introduction}

Agonist-induced phosphatidylinositol hydrolysis, first observed in the cells of the exocrine pancreas, appears to be of widespread importance in stimulus-effect coupling in numerous systems (1-3). One of the most well-studied stimulus-secretion systems is that which involves hormone-stimulated secretion of digestive enzymes from the exocrine pancreas. Currently available data, obtained from studies of pancreatic acinar cells, indicate that agonist-receptor interaction leads to activation of a phospholi-

The results of the study were reported in part at the 1985 meeting of the American Gastroenterological Association and have been published as an abstract (1985. Gastroenterology. 88:1544).

Address reprint requests to Dr. Steer, Department of Surgery, Beth Israel Hospital, 330 Brookline Avenue, Boston, MA 02115.

Received for publication 23 September 1985.

J. Clin. Invest.

(c) The American Society for Clinical Investigation, Inc. 0021-9738/86/05/1668/07 \$1.00

Volume 77, May 1986, 1668-1674 pase $C$, which cleaves phosphatidylinositol-4,5-bisphosphate $\left(\mathrm{PIP}_{2}\right)^{1}$ into inositol trisphosphate $\left(\mathrm{IP}_{3}\right)$ and 1,2-diacylglycerol (4-7). $\mathrm{IP}_{3}$ is then thought to induce a rise in the cytosolic free $\mathrm{Ca}^{2+}$ concentration by release of $\mathrm{Ca}^{2+}$ from storage pools in the endoplasmic reticulum (8). The rise in cytosolic $\mathrm{Ca}^{2+}(9,10)$ triggers a series of steps ultimately leading to secretion $(11,12)$. This secretion may be due to the phosphorylation of certain cellular proteins by calmodulin-regulated protein kinases which are activated by the increased cytosolic $\mathrm{Ca}^{2+}$ levels (13). Concomitant with the production of $\mathrm{IP}_{3}$ by phospholipase $\mathrm{C}$ is the generation of diacylglycerol, which has been reported to activate the $\mathrm{Ca}^{2+}$-, phospholipid-dependent protein kinase (protein kinase C) in many systems including the pancreas $(14,15)$. Protein kinase $\mathrm{C}$ also phosphorylates cellular proteins which may represent additional intermediate steps in stimulus-secretion coupling (16-18).

In physiologic studies, Lombardi and his co-workers $(19,20)$ observed that feeding young female mice a choline-deficient, ethionine-containing (CDE) diet caused the rapid onset of acute hemorrhagic pancreatitis. Subsequently, it was noted that secretagogue-induced secretion of digestive enzymes was inhibited in CDE-treated mice although the content of these enzymes in the cells was actually increased $(21,22)$. These observations suggested that the CDE diet administration might interfere with the processes involved in stimulus-secretion coupling, and that this defect might be related to the development of this form of experimental pancreatitis.

In this article we report studies examining the effects of the CDE diet upon the various biochemical events that couple hormonal stimulation to digestive enzyme secretion in pancreatic acinar cells. The results of these studies indicate that the CDE diet inhibits the generation of $\mathrm{IP}_{3}$ from $\mathrm{PIP}_{2}$. This biochemical lesion, which is the first reported to involve blockade of $\mathrm{IP}_{3}$ generation, appears to be the event that ultimately leads to the development of acute hemorrhagic pancreatic necrosis in this model.

\section{Methods}

Animals. Female mice (10-15 g) were fasted overnight and fed $3 \mathrm{~g}$ per animal of either a CDE diet (19) or standard laboratory diet (control) over a 24-h period. After an additional 24-h fast, mice were killed by cervical dislocation and dispersed pancreatic acini were prepared by collagenase treatment and gentle shearing as previously described (10). Acini

1. Abbreviations used in this paper: CCK, cholecystokinin; $\mathrm{CDE}$, cholinedeficient $0.5 \%$ ethionine-containing (diet); $\mathrm{IP}_{3}, \mathrm{IP}_{2}$, and $\mathrm{IP}_{1}$, inositol trisphosphate, bisphosphate, and monophosphate; $\left[{ }^{3} \mathrm{H}\right] \mathrm{NMS},\left[{ }^{3} \mathrm{H}\right] \mathrm{N}-$ methylscopolamine; OAG, 1-oleoyl-2-acetylglycerol; PI, phosphatidylinsitol; PIP, phosphatidyl-4-phosphate; PIP $_{2}$, phosphatidylinositol-4,5bisphosphate; TPA, 12-O-tetradecanoylphorbol-13-acetate. 
were resuspended in Hepes-Ringer buffer (pH 7.4) at $37^{\circ} \mathrm{C}$, which was composed of $115 \mathrm{mM} \mathrm{NaCl}, 5 \mathrm{mM} \mathrm{KCl}, 1 \mathrm{mM} \mathrm{MgSO}_{4}, 1 \mathrm{mM} \mathrm{Na}_{2} \mathrm{HPO}_{4}$, $10 \mathrm{mM}$ Hepes, $15 \mathrm{mM}$ glucose, $1.26 \mathrm{mM} \mathrm{CaCl}_{2}, 0.1 \%$ bovine serum albumin (BSA), $0.01 \%$ soybean trypsin inhibitor, and Eagle's basal amino acids. The buffer was saturated with $\mathrm{O}_{2}$. Viability of acini was $>95 \%$ as assessed by trypan blue exclusion.

$\left[{ }^{3} \mathrm{H}\right] \mathrm{N}$-methylscopolamine $\left(\left[^{3} \mathrm{H}\right] \mathrm{NMS}\right)$ binding. Aliquots of acini $(\sim 10$ $\mu \mathrm{g}$ of DNA) were resuspended in Hepes-Ringer buffer containing varying concentrations of $\left[{ }^{3} \mathrm{H}\right] \mathrm{NMS}$ in a total volume of $0.5 \mathrm{ml}$. Incubations were continued for $45 \mathrm{~min}$ under an atmosphere of $95 \% \mathrm{O}_{2}$ and $5 \% \mathrm{CO}_{2}$ in a shaking water bath at $37^{\circ} \mathrm{C}$. Incubations were terminated by the addition of $15 \mathrm{ml}$ of ice cold phosphate-buffered saline and the samples were subjected to vacuum filtration through Whatman GF/C filters (Whatman Inc., Clifton, NJ). The filters were placed into $10 \mathrm{ml}$ of Beckman Readi-Solv HP (Beckman Instruments, Inc., Fullerton, CA) and allowed to sit overnight, and the radioactivity was counted in a Packard Tri-Carb liquid scintillation counter (Packard Instrument Co., Inc., Downers Grove, IL). Nonspecific binding was defined as the bound radioactivity noted in the presence of $10^{-5} \mathrm{M}$ atropine and was typically $<10 \%$ of total binding in the presence of $0.5 \mathrm{nM}\left[{ }^{3} \mathrm{H}\right] \mathrm{NMS}$. Specific binding was defined as the difference between total binding, measured in the absence of atropine, and nonspecific binding measured in the presence of $10^{-5} \mathrm{M}$ atropine. The $K_{\mathrm{i}}$ values of agonist competition analyses were calculated by the method of Cheng and Prusoff (23).

Quin2 fluorescence. Acini were resuspended in Hepes-Ringer buffer and incubated with 20 or $50 \mu \mathrm{M}$ quin2/acetoxymethylester for $20 \mathrm{~min}$. They were then washed twice with Hepes-Ringer buffer and the quin2 fluorescence was determined as previously described (10).

Measurement of inositol phosphates. The cellular phosphatidylinositol (PI) pool was labeled by incubating acini in Hepes-Ringer buffer plus $1 \mathrm{mM} \mathrm{MnCl}{ }_{2}$ and $100 \mu \mathrm{Ci} / \mathrm{ml}$ of $\left[{ }^{3} \mathrm{H}\right]$ myoinositol for $1 \mathrm{~h}$ at $37^{\circ} \mathrm{C}$ under an atmosphere of $95 \% \mathrm{O}_{2}$ and $5 \% \mathrm{CO}_{2}$ with constant shaking. The acini were then washed once with buffer and resuspended in Hepes-Ringer buffer containing $10 \mathrm{mM} \mathrm{LiCl}$ without BSA. After a 10-min preincubation, aliquots were placed into tubes with or without secretagogues. After suitable incubation periods, $2 \mathrm{ml}$ of cold $0.6 \mathrm{~N}$ perchloric acid was added and the resulting samples were allowed to precipitate for $30 \mathrm{~min}$. After centrifugation, the supernatant was neutralized to approximately $\mathrm{pH} 8$ by addition of a neutralizing buffer $\left(0.5 \mathrm{M} \mathrm{KOH}, 9 \mathrm{mM} \mathrm{Na}_{2} \mathrm{~B}_{4} \mathrm{O}_{7}\right.$, and $1.9 \mathrm{mM}$ EDTA) and the inositol phosphates separated by ion-exchange chromotography on Dowex- $1 \times 8$, formate form $(7,24)$. Elution fractions were counted in Aquasol cocktail (New England Nuclear, Boston, MA) in the gel state. Results for inositol phosphate production are expressed as a percentage of the initial radioactivity in each inositol phosphate fraction at $t=0$. Incorporation of radioactivity into the cellular lipids was determined by extraction of the perchloric acid pellets into the organic phase of a system consisting of chloroform/methanol (2:1) and $2 \mathrm{M} \mathrm{KCl}$.

PI fractionation. Control or CDE-treated acini were loaded with $\left[{ }^{3} \mathrm{H}\right]$ myoinositol $(30 \mu \mathrm{Ci} / \mathrm{ml})$ for $2 \mathrm{~h}$. The acini were pelleted by centrifugation at $11,000 \mathrm{~g}$ for $10 \mathrm{~s}$. The pellet was placed into $5 \mathrm{ml}$ of ice-cold chloroform-methanol (2:1) and extracted against $5 \mathrm{ml}$ of $1 \mathrm{~N} \mathrm{HCl}$. An additional $5 \mathrm{ml}$ of chloroform was added and the organic layer was washed twice with cold $1 \mathrm{~N} \mathrm{HCl}$. The final organic layer was dried under nitrogen, washed twice with benzene to remove any remaining water as the azeotrope, and redissolved in chloroform. An aliquot was spotted onto a thin-layer chromatography plate of silica gel $\mathrm{H}$ with $1 \%$ potassium oxalate and developed in a phase of $\mathrm{CHCl}_{3} / \mathrm{CH}_{3} \mathrm{OH} / 4 \mathrm{~N} \mathrm{NH} \mathrm{NH}_{4} \mathrm{OH}$ (9:7:2) (25). PI, phosphatidylinositol-4-phosphate (PIP), and PIP $_{2}$ were located by radioinert standards and scraped from the plate, and the labeled compounds were quantitated by liquid scintillation counting.

The fraction of total phospholipid that is $\mathrm{PIP}_{2}$ was determined by measurement of inorganic phosphorous. Six pancreata from control or CDE-treated mice were pooled and homogenized with a Polytron (Brinkmann Instruments, Westbury, NY), extracted by the method of Schacht (26), and $\mathrm{PIP}_{2}$ separated by thin-layer chromatography as described above. $\mathrm{PIP}_{2}$ was extracted from the silica gel with the running solvent system. The PIP ${ }_{2}$ extract and aliquots of the total lipid extract were assayed for inorganic phosphorous after digestion with perchloric acid by a modification of the method of Sanui (27).

Amylase secretion. Amylase activity was measured by the method of Bernfeld (28) using soluble starch as the substrate. Secretion is reported as the net stimulated increase of amylase activity in the medium as a percent of total amylase (10). DNA was measured by the method of LaBarca and Paigen (29).

Analysis of data. Values reported are the mean \pm standard error for the number of separate experiments indicated. Groups were compared statistically by Student's $t$ test for unpaired observations, with the acceptance criteria of $P<0.05$.

Materials. Female CD-1 mice (12-15 g) were purchased from Charles River Breeding Labs, Boston, MA; EGTA, carbamylcholine $\mathrm{HCl}$, and Hepes were purchased from Sigma Chemical Co., St. Louis, MO; D,Lethionine was purchased from United States Biochemical Corp., Cleveland, OH; Quin2/acetoxymethylester was purchased from Lancaster Synthesis (United Kingdom); collagenase (CLSPA) and soybean trypsin inhibitor were purchased from Cooper Diagnostics (Freehold, NJ), Eagle's Basal Amino Acids $(100 \times)$ from Gibco (Grand Island, NY), Dowex $1 \times 8$ (formate form) from Bio-Rad Laboratories (Richmond, CA), and BSA from Miles Laboratories (Elkhart, IN); PI, PIP, and PIP $_{2}$ were purchased from Sigma Chemical Co.; silica gel $\mathrm{H}$ thin-layer plates impregnated with $1 \%$ potassium oxalate were purchased from Analtech, Inc., Newark, DE; $\left[{ }^{3} \mathrm{H}\right] \mathrm{NMS}(84.8 \mathrm{Ci} / \mathrm{mmol})$ was obtained from New England Nuclear (Boston, MA). Myo-2- ${ }^{3} \mathrm{H}(N)$-inositol $(14 \mathrm{Ci} / \mathrm{mmol}$ ) was purchased from American Radiolabeled Chemicals (St. Louis, MO). Cholecystokinin (CCK)-octapeptide was a gift from Squibb Laboratories, Princeton, NJ. All other chemicals were from common sources.

\section{Results}

Amylase secretion. Pancreatic acini that were prepared from mice fed the control diet secreted amylase in response to both carbachol and the $\mathrm{Ca}^{2+}$ ionophore, A23187, with maximal responses that were roughly equivalent (Table I). In contrast, amylase secretion from acini prepared from mice fed the CDE diet was markedly inhibited $(P<0.001)$ after stimulation with either carbachol (Table I) or CCK-octapeptide (not shown). Dose-response studies evaluating amylase secretion in acini prepared from mice fed the CDE diet showed no secretory response to any carbachol dose tested (Fig. 1). In contrast, the $\mathrm{Ca}^{2+}$ ionophore, A23187, stimulated amylase secretion from acini prepared from mice on the CDE diet. No difference was detected when A23187-induced amylase secretion was compared between acini prepared from CDE or control diet-fed animals (Table I).

Table I. Effect of CDE Diet on Stimulated Amylase Secretion from Mouse Pancreatic Acini

\begin{tabular}{lll}
\hline & Amylase & \\
\cline { 2 - 3 } Agent & Control & CDE \\
\hline$\mu M$ & \% total secreted $/ 10$ min & \% total secreted $/ 10$ min \\
$\begin{array}{c}\text { Carbachol } \\
1\end{array}$ & & \\
$\begin{array}{c}123187: \\
1\end{array}$ & $7.9 \pm 1.5(4)$ & $0.13 \pm 0.3(10)^{*}$ \\
10 & $3.5 \pm 1.2(3)$ & \\
& $5.6 \pm 1.1(3)$ & $4.1 \pm 0.8(16)$ \\
\hline
\end{tabular}

Net stimulated amylase secretion (expressed as a percentage of total over $10 \mathrm{~min}$ ) in control and CDE mouse pancreatic acini is shown. Values are mean $\pm S E$ for the number of separate experiments noted in parentheses.

* $P<0.001$ by Student's $t$ test, compared with control. 


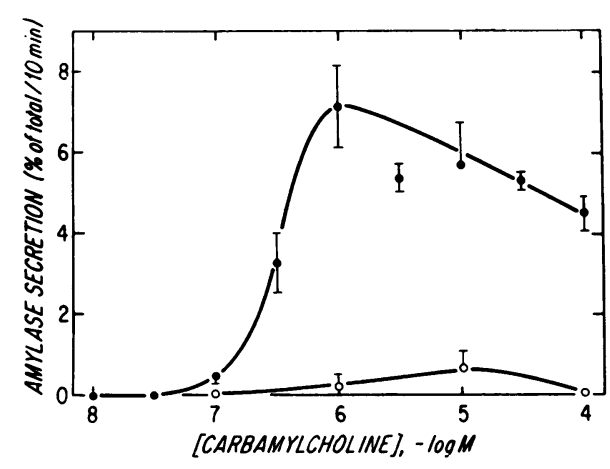

Figure 1. Amylase secretion (net stimulated as a percentage of the total amylase released/10 min) from control ( $\bullet$ ) and CDE (0) mouse pancreatic acini in response to carbachol. Points represent mean $\pm \mathrm{SE}$ for at least three experiments.

$\left[{ }^{3} H\right] N M S$ binding. To determine whether the inability of acini prepared from CDE diet-fed mice to respond to carbachol resulted from an abnormality in the cholinergic receptor, $\left[{ }^{3} \mathrm{H}\right] \mathrm{NMS}$ was used to evaluate muscarinic cholinergic binding characteristics in intact mouse pancreatic acini. Scatchard analysis of data obtained in binding studies indicated the presence of a high-affinity $\left[{ }^{3} \mathrm{H}\right] \mathrm{NMS}$-binding site with parameters similar to those observed in rat acini $(30,31)$. No difference in either the apparent dissociation constant $\left(K_{d}\right)$ or number of binding sites $\left(B_{\max }\right)$ for the antagonist was observed when acini prepared from animals fed the CDE diet were compared with those fed the control diet (Table II). Competition for $\left[{ }^{3} \mathrm{H}\right] \mathrm{NMS}$ binding by an agonist (carbachol) was also not altered in CDE-treated acini (Table II). The agonist displacement curves for control and CDE animals were superimposable (not shown). This indicates that the loss of response to carbachol in CDE-treated animals is not attributable to a loss in muscarinic cholinergic receptor function, but to some subsequent step in stimulus-secretion coupling.

Quin2 fluorescence. The resting cytosolic free $\mathrm{Ca}^{2+}$ concentrations determined by measuring quin 2 fluorescence, in acini prepared from control and CDE diet-fed mice were not different, being $82 \pm 8$ and $94 \pm 9 \mathrm{nM}$, respectively $(P>0.05)$. The agoniststimulated increase in cytosolic $\mathrm{Ca}^{2+}$ concentration was measured by monitoring the increase in quin 2 fluorescence that followed the addition of a maximally stimulating dose of carbachol $(10 \mu \mathrm{M})$ to acini prepared from either control or CDE diet-fed mice. This maximal stimulated increase in cytosolic $\mathrm{Ca}^{2+}$ was much less in acini prepared from CDE diet-fed mice (128 \pm 11 $\mathrm{nM})$ when compared to acini from control animals $(451 \pm 58$ nM) $(P<0.001)$. This indicates that the CDE diet does not alter resting $\mathrm{Ca}^{2+}$ levels but that it induces a block in stimulus-secretion coupling that reduces the agonist-stimulated increase in cytosolic free $\mathrm{Ca}^{2+}$ levels.

The secretagogue-induced rise in cytosolic free $\mathrm{Ca}^{2+}$ was not, however, totally absent in acini prepared from CDE diet-fed animals. In the presence of a maximally stimulating dose of carbachol $(10 \mu \mathrm{M})$, the cytosolic free $\mathrm{Ca}^{2+}$ concentration rose by a value of $128 \pm 11 \mathrm{nM}$ to reach a level of $230 \pm 16 \mathrm{nM}$ in acini from CDE-treated mice. A similar small increase $(99.5 \pm 31$ $n M)$ in cytosolic free $\mathrm{Ca}^{2+}$ resulting in a $\mathrm{Ca}^{2+}$ level of $192 \pm 36$ $\mathrm{nM}$ could be elicited by adding a submaximally stimulating dose of carbachol $(1 \mu \mathrm{M})$ to acini prepared from control diet-fed mice (Fig. 2). Although comparable $\mathrm{Ca}^{2+}$ increases and peak levels
Table II. Effect of CDE Diet on Binding to Muscarinic Cholinergic Receptors

\begin{tabular}{lll}
\hline Ligand & Control & CDE \\
\hline Antagonist & & \\
$B_{\max }, p m o l / m g$ & & \\
$K_{\mathrm{d}}, n M$ & $2.46 \pm 0.30$ & $2.88 \pm 0.62$ \\
Agonist & $0.65 \pm 0.12$ & $0.75 \pm 0.17$ \\
$K_{\mathrm{i}}, \mu M$ & & \\
& $36 \pm 15$ & $49 \pm 15$ \\
\hline
\end{tabular}

Mouse pancreatic acini were incubated with varying concentrations of $\left[{ }^{3} \mathrm{H}\right] \mathrm{NMS}$, as described in the text, to characterize antagonist binding to the muscarinic cholinergic receptor. Agonist binding was evaluated by measuring the inhibition of $\left[{ }^{3} \mathrm{H}\right] \mathrm{NMS}(1 \mathrm{nM})$ binding induced by varying concentrations of carbachol and the $K_{\mathrm{i}}$ calculated as described by Cheng and Prusoff (23). Results represent mean $\pm S E$ values from three or four separate experiments.

could be reached by using these different concentrations of agonist in acini from control and CDE diet mice, the secretion of amylase under these conditions was strikingly different. Amylase secretion from control acini was still 2.9 times that released from CDE acini (Fig. 2). This finding indicates that the lesion induced by the CDE diet is more complex than the mere interference with $\mathrm{Ca}^{2+}$ release and that another abnormality (see Discussion) may also be induced by the CDE diet.

Inositol phosphate production. Feeding the CDE diet does not appear to alter either the basal polyphosphatide or inositol phosphate metabolism. Mouse pancreatic acini incubated with $\left[{ }^{3} \mathrm{H}\right]$ myoinositol incorporated radioactivity to a comparable extent whether prepared from control $(5,629 \pm 587 \mathrm{dpm} / \mu \mathrm{g}$ DNA, $n=4)$ or CDE-treated (5,540 $\pm 1,307 \mathrm{dpm} / \mu \mathrm{g}$ DNA, $n=3)$ mice. The level of $\mathrm{PIP}_{2}$ (expressed as a percentage of total lipid phosphorous) was $0.16 \pm 0.03 \%$ for the control pancreas and $0.15 \pm 0.1 \%$ in CDE-treated pancreas (three separate determinations for each group). In addition, the labeling of PI and the polyphosphoinositides by $\left[{ }^{3} \mathrm{H}\right]$ myoinositol was not different between control and CDE-treated acini (Table III). The resting levels of tritiated insitol trisphosphate, bisphosphate, and monophosphate $\left(\left[{ }^{3} \mathrm{H}\right] \mathrm{IP}_{3},\left[{ }^{3} \mathrm{H}\right] \mathrm{IP}_{2}\right.$, and $\left.\left[{ }^{3} \mathrm{H}\right] \mathrm{IP} \mathrm{P}_{1}\right)$ were not altered $(P$ $>0.05$ ) in acini prepared from mice fed the CDE diet when compared to control animals (see legend to Fig. 3).

Control mouse acini generated radiolabeled $\mathrm{IP}_{3}, \mathrm{IP}_{2}$, and $\mathrm{IP}_{1}$ in response to either carbachol or caerulein stimulation (Fig. 3). Secretagogue-stimulated $\left[{ }^{3} \mathrm{H}\right] \mathrm{IP}_{3}$ production was rapid and dose-dependent. Maximal levels of $\left[{ }^{3} \mathrm{H}\right] \mathrm{IP}_{3}$ were observed within $5 \mathrm{~s}$ of secretagogue addition and the elevated levels of $\left[{ }^{3} \mathrm{H}\right] \mathrm{IP}_{3}$

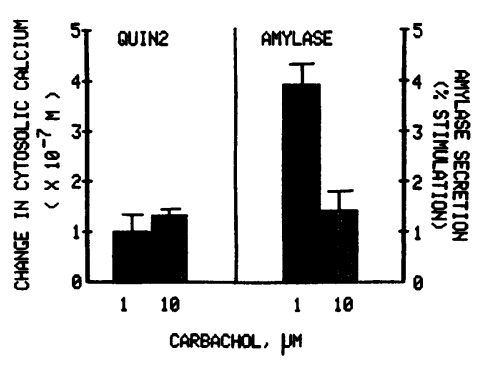

Figure 2. Change in cytosolic free $\mathrm{Ca}^{2+}$ levels, as determined by the quin 2 fluorescence change (left), and amylase secretion as the net stimulated secretion, \% of total/10 min (right). Control mouse pancreatic acini (solid bars) were treated with $1 \mu \mathrm{M}$ carbachol and CDE acini (striped bars)

were treated with $10 \mu \mathrm{M}$ carbachol to give equivalent quin2 responses. Values are mean \pm SE for between four and eight separate experiments. 
Table III. Incorporation of $\left[{ }^{3} \mathrm{H}\right]$ Myoinositol into Pancreatic Acini Phospholipids

\begin{tabular}{lll}
\hline & Control & CDE \\
\hline & \% of total cpm & \% of total cpm \\
PI & $90.1 \pm 2.0$ & $91.7 \pm 1.4$ \\
PIP & $2.8 \pm 0.6$ & $2.6 \pm 0.5$ \\
PIP & $1.8 \pm 0.06$ & $1.6 \pm 0.2$ \\
\hline
\end{tabular}

Acini were labeled for $2 \mathrm{~h}$ with $\left[{ }^{3} \mathrm{H}\right]$ myoinositol $(30 \mu \mathrm{Ci} / \mathrm{ml})$. The phospholipids were then extracted and separated by thin-layer chromatography as described in Methods. Results are expressed as the percent of the total CPM applied to the plate in each phosphoinositide fraction. Values are the mean \pm SE for three separate determinations.

remained constant for $5 \mathrm{~min}$ in the presence of $10 \mathrm{mM} \mathrm{LiCl}$ (32). Acini prepared from mice fed the CDE diet also produced $\left[{ }^{3} \mathrm{H}\right]\left[\mathrm{P}_{3}\right.$ and $\left[{ }^{3} \mathrm{H}\right] \mathrm{IP}_{2}$ in response to carbachol stimulation, but at a much lower level than acini prepared from control diet-fed mice (Fig. 3). The levels of $\left[{ }^{3} \mathrm{H}\right] \mathrm{IP}_{3}$ and $\left[{ }^{3} \mathrm{H}\right] \mathrm{IP} \mathrm{P}_{2}$ measured in acini from animals fed the CDE diet were significantly less $(P$ $<0.05$ ) than those in acini from animals fed the control diet at all carbachol doses examined. $\left[{ }^{3} \mathrm{H}\right] \mathrm{IP}_{3}$ production in CDE-fed mouse acini was only $33 \%$ of that noted in acini from control diet-fed animals after the addition of $10^{-5} \mathrm{M}$ carbachol, a dose that gave maximal amylase secretion from control acini. No production of $\left[{ }^{3} \mathrm{H}\right] I \mathrm{P}_{1}$ was detected in acini from $\mathrm{CDE}$-fed mice in response to any concentration of carbachol tested. These results indicate that the CDE diet interferes with the generation
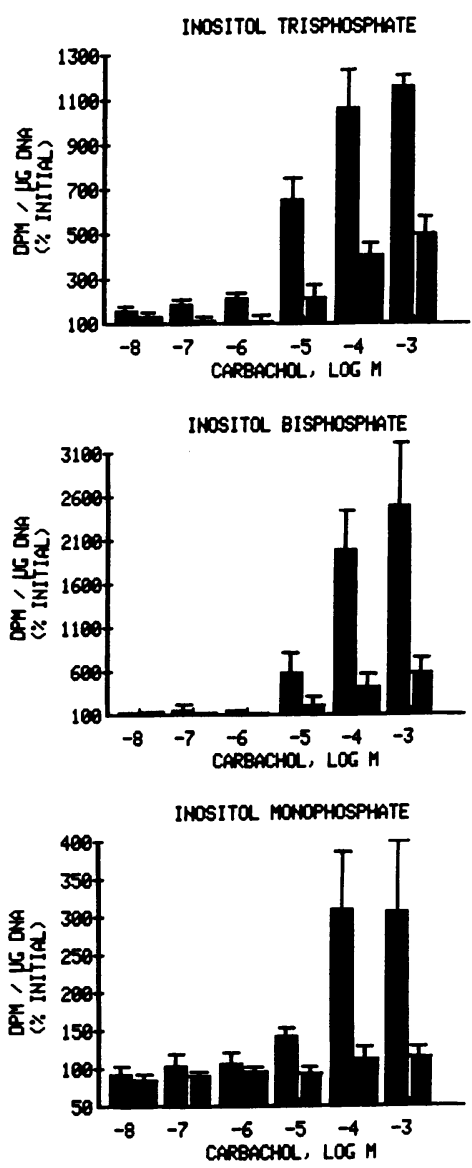

Figure 3. $\left[{ }^{3} \mathrm{H}\right] \mathrm{IP}_{3},\left[{ }^{3} \mathrm{H}\right] \mathrm{IP}_{2}$, and $\left[{ }^{3} \mathrm{H}\right] \mathrm{IP} \mathrm{P}_{1}$ generation in dispersed mouse pancreatic acini in response to carbachol. Incubations were performed for $5 \mathrm{~min}$ in the presence of $10 \mathrm{mM} \mathrm{LiCl}$. Results represent the level of each $\left[{ }^{3} \mathrm{H}\right] \mathrm{IP}$ as a percentage of the initial disintegrations per minute in the incubation. Initial values (dpm/ $\mu \mathrm{g}$ DNA) for $\left[{ }^{3} \mathrm{H}\right] \mathrm{IP}_{1}$, $\left[{ }^{3} \mathrm{H}\right]\left[\mathrm{P}_{2}\right.$, and $\left[{ }^{3} \mathrm{H}\right] \mathrm{IP} \mathrm{P}_{3}$ were $1,341 \pm 146,61 \pm 16$, and $50 \pm 8$ for control acini and $1,281 \pm 318,42 \pm 20$, and $29 \pm 9$ for CDE-treated acini respectively. Values represent the mean \pm SE for three separate experiments in each group. There are no statistical differences between the individual initial IP values for the two groups $(P>0.05)$. of inositol phosphates in mouse pancreatic acini, and that this is not the result of a decrease in phospholipase $\mathrm{C}$ substrate (i.e., $\mathrm{PIP}_{2}$ ) levels in the CDE-treated acini.

Protein kinase $C$ activators. Mouse pancreatic acini secreted amylase in response to compounds that have been reported to mimic the action of diacylglycerol to stimulate protein kinase $\mathrm{C}$ activity: a phorbol ester, 12-O-tetradecanoylphorbol-13-acetate (TPA) and a synthetic diacylglycerol, 1-oleoyl-2-acetylglycerol (OAG). Maximal secretion to these compounds was, however, only $\sim 40 \%$ of the maximal response observed to carbachol. Amylase secretion in response to maximally stimulating doses of these compounds was not different between control and CDEtreated mouse pancreatic acini (Table IV). These data are consistent with our hypothesis that the CDE diet-induced lesion blocks stimulus-secretion coupling at a step preceding the hydrolysis of the phosphoinositides, as demonstrated by the decreased inositol phosphate generation. Concomitant with this would be a decrease in the production of diacylglycerol. The finding that the secretory response is not different between the control and CDE-treated groups after stimulation with a phorbol ester or a synthetic diacylglycerol indicates that the primary block must precede the generation of endogenous diacylglycerol.

\section{Discussion}

The digestive enzyme content and number of zymogen granules in pancreatic acinar cells is increased within $24 \mathrm{~h}$ after young female mice are fed the CDE diet (21). Our previously reported biochemical and morphologic studies have indicated that this occurs because the CDE diet blocks digestive enzyme secretion while digestive enzyme synthesis and intracellular transport to the zymogen granule compartment continue unimpeded (21, 22). Prior studies, however, have not examined the mechanism by which the CDE diet interferes with secretion.

It is generally believed that the biochemical pathway that leads to digestive enzyme secretion by pancreatic acinar cells requires the secretagogue-induced elevation of cytosolic $\mathrm{Ca}^{2+}$ levels $(11,12)$. Our observation that the $\mathrm{Ca}^{2+}$ ionophore $\mathrm{A} 23187$ can induce secretion from acini made unresponsive to the muscarinic cholinergic secretagogue carbachol by the CDE diet (Table I) indicates that these acini retain the ability to secrete digestive enzymes once cytosolic $\mathrm{Ca}^{2+}$ levels are increased. This finding suggests that the CDE diet interferes with the process of secretagogue-induced elevation of cytosolic $\mathrm{Ca}^{2+}$. Support for this conclusion is provided by our studies that utilized the $\mathrm{Ca}^{2+}$ -

Table IV. Stimulation of Amylase Secretion from Mouse Pancreatic Acini by Protein Kinase C Activators

\begin{tabular}{lll}
\hline & \multicolumn{1}{l}{ Amylase } & \\
\cline { 2 - 3 } Agent & Control & CDE \\
\hline & \% total secreted $/ 30 \mathrm{~min}$ & \% total secreted/30 min \\
Carbachol, $1 \mu \mathrm{M}$ & $7.9 \pm 1.5(4)$ & $0.13 \pm 0.3(10)$ \\
TPA, $1 \mu \mathrm{M}$ & $4.4 \pm 1.0(9)$ & $4.7 \pm 0.9(10)$ \\
OAG, $40 \mathrm{ng} / \mathrm{ml}$ & $3.5 \pm 0.7(3)$ & $4.9 \pm 0.7(5)$
\end{tabular}

Acini were prepared from control or CDE-diet fed mice. The acini were incubated for $30 \mathrm{~min}$ in the presence of a maximally stimulating dose of either agonist. Values represent the mean $\pm \mathrm{SE}$ for the number of separate experiments indicated in parentheses. 
sensitive fluorescent probe quin2 to measure changes in the cytosolic free $\mathrm{Ca}^{2+}$ concentration after carbachol addition. Only a small change in the concentration of cytosolic $\mathrm{Ca}^{2+}$ followed addition of the secretagogue (Table III).

Failure of the secretagogue to elevate cytosolic $\mathrm{Ca}^{2+}$ levels and stimulate amylase secretion could indicate that the CDE diet had simply caused a loss of receptor function. To determine whether the CDE diet-induced loss of stimulable secretion was a receptor or postreceptor effect, we examined the effect of the diet on muscarinic cholinergic receptors by characterizing the binding of the radiolabeled antagonist $\left[{ }^{3} \mathrm{H}\right] \mathrm{NMS}$ to acini prepared from mice fed the control or CDE diet. No change in either the calculated number of NMS receptors (i.e., $B_{\max }$ ) or dissociation constant for [ $\left.{ }^{3} \mathrm{H}\right] \mathrm{NMS}$ (i.e., $K_{d}$ ) was noted (Table II). In addition, there was no difference in the agonist competition for $\left[{ }^{3} \mathrm{H}\right] \mathrm{NMS}$ binding between control and CDE-treated acini (Table I). Thus, by exclusion, these findings indicate that the lesion induced by the CDE diet involves the process of stimulus-secretion coupling at a step subsequent to hormone-receptor binding and prior to $\mathrm{Ca}^{2+}$ mobilization.

Studies in the pancreas recently reported by Streb et al. (8), and supported by numerous experiments performed using other tissues (33), have shown that hormone-receptor occupancy leads to the hydrolysis of membrane phospholipids with the release of $1,4,5-\mathrm{IP}_{3}$ and that $1,4,5-\mathrm{IP}_{3}$ causes a rise in cytosolic $\mathrm{Ca}^{2+}$ levels by mobilizing $\mathrm{Ca}^{2+}$ from stores within the endoplasmic reticulum. To further define the lesion induced by the CDE diet, we performed studies to evaluate the generation of inositol phosphates in acini prepared from animals fed the CDE or control diets.

The CDE diet did not significantly alter the observed resting levels of $\left[{ }^{3} \mathrm{H}\right] I \mathrm{P}_{3},\left[{ }^{3} \mathrm{H}\right] I \mathrm{IP}_{2}$, and $\left[{ }^{3} \mathrm{H}\right] \mathrm{IP} \mathrm{P}_{1}$, in acini preloaded with $\left[{ }^{3} \mathrm{H}\right]$ myoinositol, when compared to control acini. However, secretagogue-induced increases in these labeled inositol phosphates were severely inhibited by the CDE diet. The rises in $\left[{ }^{3} \mathrm{H}\right] \mathrm{IP} \mathrm{P}_{3}$ and $\left[{ }^{3} \mathrm{H}\right] I \mathrm{P}_{2}$ were markedly reduced while that of $\left[{ }^{3} \mathrm{H}\right] \mathrm{IP} \mathrm{P}_{1}$ was prevented by the CDE diet (Fig. 3). These findings indicate that the inability of the muscarinic cholinergic agonist to increase cytosolic $\mathrm{Ca}^{2+}$ and stimulate amylase secretion from acini prepared from mice fed the CDE diet is a consequence of the inability of carbachol to stimulate phospholipase $C$ hydrolysis of $\mathrm{PIP}_{2}$ and generation of $\mathrm{IP}_{3}$ in these acini. ${ }^{2}$

Hydrolysis of $\mathrm{PIP}_{2}$ by phospholipase $\mathrm{C}$ generates diacylglycerol in addition to $\mathrm{IP}_{3}$. Diacylglycerol also stimulates secretion, but this effect is mediated by stimulation of the recently identified enzyme protein kinase $\mathrm{C}$ rather than release of cytoplasmic $\mathrm{Ca}^{2+}$ $(14,33,35)$. The hypothesis that the CDE diet results in reduced phospholipase $\mathrm{C}$ activity would, therefore, also suggest that the CDE diet causes a decrease in agonist-induced diacylglycerol generation. Support for this conclusion comes from our observation that acini prepared from mice fed the CDE diet can be stimulated to secrete amylase by addition of the synthetic diacylglycerol, OAG, and by the phorbol ester, TPA, equally well when compared to control acini.

In the pancreas, the $\mathrm{Ca}^{2+}$-dependent and the protein kinase C-dependent pathways for stimulation of secretion are believed to complement each other with synergism occurring when both

2. Irvine et al. (34) have reported that two isomers of $\mathrm{IP}_{3}$ are produced after stimulation, the $\mathrm{Ca}^{2+}$-releasing $1,4,5-\mathrm{IP}_{3}$ and a nonactive $1,3,4-\mathrm{IP}_{3}$. The column separation technique can not resolve these two compounds; therefore the $\mathrm{IP}_{3}$ data include the measurement of both isomers. pathways are stimulated, as for example by addition of a $\mathrm{Ca}^{2+}$ ionophore and one of the protein kinase $\mathrm{C}$-stimulating phorbol esters (36-39). We have observed that both the $\mathrm{IP}_{3}$ levels and the cytosolic $\mathrm{Ca}^{2+}$ levels can be modestly elevated by carbachol in CDE-treated acini, but even under these conditions amylase secretion remains below that noted after comparable elevations of cytosolic $\mathrm{Ca}^{2+}$ in acini prepared from mice fed the control diet (Fig. 2). This observation is consistent with the hypothesis that the $\mathrm{CDE}$ diet interferes with both $\mathrm{IP}_{3}$ and diacyglycerol production by phospholipase $\mathrm{C}$, in that the effect of decreased secretion cannot be completely attributed to a reduction in the degree of $\mathrm{Ca}^{2+}$ mobilization. This also may suggest the presence of a second lesion at a point in stimulus-secretion coupling beyond the release of $\mathrm{Ca}^{2+}$ in the cells. This observation is made more interesting by the fact that comparable secretion by control and CDE-treated acini can be elicited by activation of either the $\mathrm{Ca}^{2+}$-dependent (ionophore) or protein kinase C (TPA or OAG) pathways, separately. This suggests that the disparity in secretion may result from a lack of synergism or interaction between the two pathways.

To determine the nature of the precise biochemical defect by which the $\mathrm{CDE}$ diet prevents $\mathrm{IP}_{3}$ generation, several possible mechanisms must be examined. One possibility that we examined was that the CDE-induced lesion could cause a decrease in the amount of $\mathrm{PIP}_{2}$ in the acinar cells, thereby depleting the substrate for phospholipase $\mathrm{C}$. We found, however, that the level of $\mathrm{PIP}_{2}$ (expressed as a percentage of total pancreatic phospholipid) was comparable between the control and CDE-treated mice. These determinations were based on measuring the mass of the phospholipids by assaying lipid phosphorous. Further, loading studies with $\left[{ }^{3} \mathrm{H}\right]$ myoinositol in acini from control and CDE-diet mice revealed that the incorporation of the $\left[{ }^{3} \mathrm{H}\right]$ myoinositol into cellular lipid was similar and, therefore, that PI-kinase and PIP-kinase activity was comparable between the two groups. These data demonstrate that the decrease in agonist-stimulated inositol phosphate generation in CDE-treated pancreatic acini is not due to a depletion of the substrate for phospholipase C, i.e., PIP $_{2}$.

Among other possibilities to be examined are alterations in the membrane phospholipid composition that could modulate phospholipase $\mathrm{C}$ activity. Membrane phospholipids have been reported to regulate phospholipase $C$ activity in vitro $(40,41)$. $S$-adenosylethionine, a product formed after the CDE treatment is an ethyl-group donor and interferes with $S$-adenosylmethionine-dependent methylations (42). Such methylations are involved in choline synthesis. Thus, the CDE diet could lead to changes in membrane lipid composition and fluidity and thereby modulate phospholipase $\mathrm{C}$ activity. An alternative hypothesis involves the recently proposed involvement of a GTP-binding protein as a coupling step between receptor and phospholipase $C(43-45)$. The CDE diet may alter the structure and/or function of this component leading to a loss in receptor-phospholipase coupling and, thus, diminished PI hydrolysis.

In summary, the observations reported in this communication demonstrate that the CDE diet interferes with stimulussecretion coupling in mouse pancreatic acinar cells by preventing $\mathrm{IP}_{3}$ (and possibly diacylglycerol) generation from $\mathrm{PIP}_{2}$ by the action of phospholipase $C$. In addition, the decreased production of $\mathrm{IP}_{2}, \mathrm{IP}_{1}$, and diacylglycerols from the breakdown of PIP and PI could also have a role in explaining the effects of the CDE diet on secretion apart from a direct effect on cytosolic $\mathrm{Ca}^{2+}$. To our knowledge, this is the first report of cellular pathology which 
can be related to a derangement in inositol phosphate generation. Inhibition of digestive enzyme secretion causes zymogen granules to accumulate eventually leading to fusion of these granules with lysosomes by crinophagy, intrapancreatic digestive enzyme activation, and acute hemorrhagic pancreatic necrosis $(21,22$, 46, 47).

\section{Acknowledgments}

The authors would like to thank Ms. Susan F. Eigner and Dr. Manju Saluja for their excellent technical assistance and Dr. Subhash Gumber of Brandeis University for his advice on the phosphate assay.

This research was supported by National Institutes of Health grants AM-31914 and AM-31396.

\section{References}

1. Hokin, M. R., and L. E. Hokin. 1953. Enzyme secretion and the incorporation of ${ }^{32} \mathrm{P}$ into phospholipids of pancreas slices. J. Biol. Chem. 203:967-977.

2. Hokin, L. E., and M. R. Hokin. 1956. The actions of pancreozymin in pancreas slices and role of phospholipids in enzyme secretion. J. Physiol. (Lond.). 132:442-453.

3. Hokin, L. E., and M. R. Hokin. 1955. Effects of acetylcholine on the turnover of phosphoryl units in individual phospholipids of pancreatic slices and brain cortex slices. Biochim. Biophys. Acta. 18:102-110.

4. Putney, J. W., G. M. Burgess, S. P. Halenda, J. S. McKinney, and R. P. Rubin. 1983. Effects of secretagogues on ${ }^{32}$ P-phosphatidylinositol4,5-bisphosphate metabolism in the exocrine pancreas. Biochem. J. 212: 483-488.

5. Orchard, J. L., J. S. David, R. E. Larson, and R. V. Farese. 1984. Effects of carbachol and pancreozymin (cholecystokinin-octapeptide) on polyphosphoinositide metabolism in the rat pancreas in vitro. Biochem. J. 217:281-287.

6. Rubin, R. P., P. P. Godfrey, D. A. Chapman, and J. W. Putney, Jr. 1984. Secretagogue induced formation of inositol phosphates in rat exocrine pancreas: Implicators for a messenger role for inositol trisphosphate. Biochem. J. 219:655-659.

7. Rubin, R. P. 1984. Stimulation of inositol trisphosphate accumulation and amylase secretion by caerulein in pancreatic acini. J. Pharmacol. Exp. Ther. 231:623-627.

8. Streb, H., R. F. Irvine, M. J. Berridge, and I. Schulz. 1983. Release of $\mathrm{Ca}^{2+}$ from a non-mitochondrial intracellular store in pancreatic acinar cells by inositol-1,4,5-trisphosphate. Nature (Lond.). 306:67-69.

9. Ochs, D. L., J. I. Korenbrot, and J. A. Williams. 1983. Intracellular free $\mathrm{Ca}^{2+}$ concentration in isolated pancreatic acini: effects of secretagogues. Biochem. Biophys. Res. Commun. 117:122-128.

10. Powers, R. E., P. C. Johnson, M. J. Houlihan, A. K. Saluja, and M. L. Steer. 1985. Intracellular $\mathrm{Ca}^{2+}$ levels and amylase secretion in Quin 2-loaded mouse pancreatic acini. Am. J. Physiol. 248 (Cell Physiol. 17) C535-C541.

11. Schulz, I. 1980. Messenger role of calcium in function of pancreatic acinar cells. Am. J. Physiol. 239:G335-G347.

12. Williams, J. A. 1980. Regulation of pancreatic acinar cell function by intracellular calcium. Am. J. Physiol. 238:G269-G279.

13. Burnham, D. B., and J. A. Williams. 1984. Activation of protein kinase activity in pancreatic acini by calcium and cAMP. Am. J. Physiol 246:G500-G508.

14. Gunther, G. R. 1981. Effect of 12-O-tetradecanoyl-phorbol-13acetate on $\mathrm{Ca}^{2+}$ efflux and protein discharge in pancreatic acini. J. Biol. Chem. 256:12040-12045.

15. Wooten, M. W., and R. W. Wrenn. 1984. Phorbol ester induces intracellular translocation of phospholipid/ $\mathrm{Ca}^{2+}$-dependent protein kinase and stimulates amylase secretion in isolated pancreatic acini. FEBS (Fed. Eur. Biochem. Soc.) Lett. 171:183-186.

16. Wrenn, R. W. 1983. Phospholipid-sensitive calcium-dependent protein kinase and its endogenous substrate proteins in rat pancreatic acinar cells. Life Sci. 32:2385-2392.

17. Wrenn, R. W. 1984. Phosphorylation of a pancreatic zymogen granule membrane protein by endogenous calcium/phospholipid-dependent protein kinase. Biochim. Biophys. Acta. 775:1-6.

18. Burnham, D. B., and J. A. Williams. 1984. Stimulus-secretion coupling in pancreatic acinar cells. J. Pediatr. Gastroenterol. Nutr. 3(Suppl. 1.).

19. Lombardi, B., L. W. Estes, and D. S. Longnecker. 1975. Acute hemorrhagic pancreatitis (massive necrosis) with fat necrosis induced in mice by DL-ethionine fed with a choline deficient diet. Am. J. Pathol. 79:464-480.

20. Lombardi, B., and N. K. Rao. 1975. Acute hemorrhagic pancreatic necrosis in mice: influence of the age and sex of the animals and of dietary ethionine, choline, methionine and adenine sulfate. Am. J. Pathol. 81:87-100.

21. Gilliland, L., and M. L. Steer. 1980. Effects of ethionine on digestive enzyme synthesis and discharge by mouse pancreas. Am. J. Physiol. 239:G418-G426.

22. Koike, H., M. L. Steer, and J. Meldolesi. 1982. Pancreatic effects of ethionine: blockade of exocytosis and appearance of crinophagy and autophagy precede cellular necrosis. Am. J. Physiol. 242:G297-G307.

23. Cheng, Y., and W. H. Prusoff. 1973. Relationship between the inhibition constant $\left(\mathrm{K}_{\mathrm{i}}\right)$ and the concentration of inhibitor which causes 50 percent inhibition $\left(\mathrm{IC}_{50}\right)$ of an enzymatic reaction. Biochem. Pharmacol. 22:3099-3108.

24. Berridge, M. J. 1983. Rapid accumulation of inositol trisphosphate reveals that agonists hydrolyse polyphosphoinositides instead of phosphotidylinositol. Biochem. J. 212:849-858.

25. Gonzales-Sostre, F., and J. Folch-Pi. 1968. Thin-layer chromatography of the phosphoinositides. J. Lipid Res. 9:532-533.

26. Schacht, J. 1981. Methods Enzymol. 72:626-631.

27. Sanui, H. 1974. Measurement of inorganic phosphate in biological methods: extraction properties of butyl acetate. Anal. Biochem. 60:489504.

28. Bernfeld, P. 1955. Methods Enzymol. 1:149.

29. LaBarca, C., and K. Paigen. 1980. A simple, rapid, and sensitive DNA assay procedure. Anal. Biochem. 102:344-352.

30. Appert, H. E., T. H. Chiu, G. C. Budd, A. J. Leonardi, and J. M. Howard. 1981. ${ }^{3} \mathrm{H}-\mathrm{N}$-methylscopolamine binding to dispersed pancreatic acini. Cell Tissue Res. 220:673-684.

31. DeHaye, J. P., J. Winand, P. Poloczck, and J. Christophe. 1984. Characterization of muscarinic cholinergic receptors on rat pancreatic acini by ${ }^{3} \mathrm{H}-\mathrm{N}$-methylscopolamine binding. J. Biol. Chem. 259:294-300.

32. Powers, R. E., A. K. Saluja, M. J. Houlihan, and M. L. Steer. 1985. Inositol trisphosphate production and amylase secretion in mouse pancreatic acini. Biochem. Biophys. Res. Commun. 131:284-288.

33. Berridge, M. K. 1984. Inositol trisphosphate and diacylglycerol as second messengers. Biochem. J. 220:345-360.

34. Irvine, R. F., E. E. Anggard, A. J. Letcher, and C. P. Downes. 1985. Metabolism of inositol-1,4,5-trisphosphate and inositol-1,3,4-trisphosphate in rat parotid glands. Biochem. J. 229:505-511.

35. Grzeskowiak, M., V. Della Bianca, P. DeTogni, E. Papini, and F. Rossi. 1985. Independence with respect to $\mathrm{Ca}^{2+}$ changes of the neutrophil respiratory and secretory response to exogenous phospholipase $\mathrm{C}$ and possible involvement of diacylglycerol and protein kinase $\mathrm{C}$. Biochim. Biophys. Acta. 884:81-90.

36. Putney, J. W., Jr, J. S. McKinney, D. L. Aub, and B. A. Leslie. 1984. Phorbol ester induced protein secretion in rat parotid gland. Relationship to the role of inositol lipid breakdown and protein kinase C activation in stimulus-secretion coupling. Mol. Pharmacol. 26:261-266.

37. Logsdon, C. D., and J. A. Williams. 1984. Intracellular $\mathrm{Ca}^{2+}$ and phorbol esters synergestically inhibit internalization of epidermal growth factor in pancreatic acini. Biochem. J. 223:893-900.

38. dePont, J. J., and A. M. Fleuren-Jacobs. 1984. Synergistic effect of A23187 and a phorbol ester on amylase secretion from rabbit pancreatic acini. FEBS (Fed. Eur. Biochem. Soc.) Lett. 170:64-68. 
39. Singh, J. 1985. Phorbol ester (TPA) potentiates noradrenaline and acetylcholine-evoked amylase secretion in the rat pancreas. FEBS (Fed. Eur. Biochem. Soc.) Lett. 180:191-195.

40. Irvine, R. F., N. Hemington, and R. M. Dawson. 1979. The calcium-dependent phosphatidylinositol-phosphodiesterase of rat brain: mechanisms of suppression and stimulation. Eur. J. Biochem. 99:525530 .

41. Wilson, D. B., T. E. Bross, S. L. Hofmann, and P. W. Majerus. 1984. Hydrolysis of polyphosphoinositides by purified sheep vesicle phospholipase C enzymes. J. Biol. Chem. 259:11718-11724.

42. Farber, E. 1963. Ethonine carcinogenesis. Adv. Cancer Res. 7: 383-474.

43. Haslam, R. J., and M. M. L. Davidson. 1984. Receptor-induced diacylglycerol formation in permeabilized platelets: possible role for a GTP-binding protein. J. Recept. Res. 4:605-629.

44. Shefcyk, J., R. Yassin, M. Volpi, T. F. P. Molski, P. H. Naccache, J. J. Munoz, E. L. Becker, M. B. Feinstein, and R. I. Sha'afi. 1985.
Pertussis but not cholera toxin inhibits the stimulated increase in actin association with the cytoskeleton in rabbit neutrophils: role of the "G proteins" in stimulus-response coupling. Biochem. Biophys. Res. Commun. 126:1174-1181.

45. Molski, T. F. P., P. H. Naccache, M. L. Marsh, J. Kermode, E. L. Becker, and R. I. Sha'afi. 1984. Pertussis toxin inhibits the rise in the intracellular concentration of free calcium that is induced by chemotactic factors in rabbit neutrophils: possible role of the "G proteins" in calcium mobilization. Biochem. Biophys. Res. Commun. 124:644650 .

46. Rao, K. N., J. Tuma, and B. Lombardi. 1975. Acute hemorrhagic pancreatic necrosis in mice. Intraparenchymal activation of zymogens and other enzyme changes in pancreas and serum. Gastroenterology. 70: 720-726.

47. Steer, M. L., C. Figarella, and J. Meldolesi. 1984. Pancreatitis: the role of lysosomes. Dig. Dis. Sci. 29:934-938. 